\title{
Variation in age, growth and maturity in the Australian arrow squid Nototodarus gouldi over time and space - what is the pattern?
}

\author{
George D. Jackson ${ }^{1, *}$, Belinda McGrath Steer $^{1}$, Simon Wotherspoon ${ }^{2}$, \\ Alistair J. Hobday ${ }^{3}$ \\ ${ }^{1}$ Institute of Antarctic and Southern Ocean Studies, University of Tasmania, Private Bag 77, Hobart, Tasmania 7001, Australia \\ ${ }^{2}$ Department of Maths \& Physics, University of Tasmania, Private Bag 37, Hobart, Tasmania 7001, Australia \\ ${ }^{3}$ CSIRO Marine Research, GPO Box 1538, Hobart, Tasmania 7001, Australia
}

\begin{abstract}
Age, growth and maturity parameters were examined for the southern Australian ommastrephid squid Nototodarus gouldi. Squid were obtained from the fishing ports of: Ulladulla, New South Wales; Port Lincoln, South Australia; Lakes Entrance, Victoria; and Hobart, Tasmania. Squid were collected during 2 seasonal periods: summer/autumn-caught (warm-season squid) and spring-caught (cool-season squid) over 2 consecutive years $(2000,2001)$. N. gouldi is a sexually dimorphic species, with females generally reaching larger sizes than males. Initial genetic analysis has found only a single species in Australian waters. Statolith ageing revealed that squid completed their life cycle in $<1 \mathrm{yr}$, and appear to hatch throughout the year. Trends in size, growth and maturity varied considerably between sites, seasons and years. Squids hatched in summer/autumn grew consistently faster than squid that hatched in winter/spring, presumably due to the influence of temperature on growth. Squid in 1999/2000 also grew faster than squid in 2000/2001. Growth of female squid in winter correlated with sea surface colour (SSC) during peak hatch periods, but the SSC relationship did not exist for males. Ulladulla squid were generally smaller, younger, had smaller gonads than most other squid and were possibly a smaller morph of the species. Tasmania and Lakes Entrance tended to have larger older individuals with larger gonads, while Port Lincoln was variable and intermediate. However, during spring 2001 both Tasmania and Port Lincoln had individuals that were much smaller than those of the other seasons for these sites, and were more like those from Ulladulla. Trends in age of mature individuals showed considerable variability (over $100 \mathrm{~d}$ from youngest to oldest) and there appeared to be a cline across all sites and seasons. Arrow squid appear to reveal marked plasticity in age, growth and maturity parameters, but currently the extent to which the environment or genetics control plasticity is unclear.
\end{abstract}

KEY WORDS: Ommastrephid squid $\cdot$ Cephalopod $\cdot$ Population dynamics $\cdot$ Statoliths $\cdot$ Age $\cdot$ Growth Resale or republication not permitted without written consent of the publisher

\section{INTRODUCTION}

The study of squid age, growth and population dynamics continues to be of topical interest. The short life spans and rapid turnover in populations make them ideal marine models for studying population dynamics and how environmental influences may modify growth. Rapid growth rates along with physiological strategies aimed at maintaining 'life in the fast lane' (Jackson \& O'Dor 2001) place squid in a unique position to respond to environmental or climatic changes. The spawning population of squid reflect conditions only experienced during the current year, because of the short generation time. It has been suggested that the life-styles of squid promote faster changes in gene frequency than many other organisms (they are more like insects than vertebrates) and that because of this, squid should be able to track changes 
in climate or biological conditions more efficiently (O'Dor 1998). There have also been observations of large inter-annual fluctuations of squid, ranging from 'plagues' (Rodhouse 2001) to population crashes (O'Dor 1992). Parallels in squid life histories have been made to terrestrial weeds (O'Dor 1998) and even locusts (Rodhouse 2001). Indeed, recent work (Jackson \& Domeier 2003) has proposed that squid are effective ecological indicators, with phenotypic variability in Loligo opalescens rapidly changing in response to upwelling and productivity variation in the California Current as a result of short-term El Niño/La Niña influences.

There is now a substantial body of work that has demonstrated the marked influence of temperature or season on size, growth rates and life spans of both loliginid (Jackson et al. 1997, Hatfield 2000, Forsythe et al. 2001, Hatfield et al. 2001, Jackson \& Moltschaniwskyj 2001，2002, Macy \& Brodziak 2001) and ommastrephid (Dawe \& Beck 1997, Arkhipkin et al. 2000, Arguelles et al. 2001) squids. Oceanographic conditions can also be an important influence on the successful growth, abundance and survival of squid (Waluda et al. 2001, Agnew et al. 2002, Garrison et al. 2002, Kang et al. 2002). In waters of high productivity or high plankton biomass, standing stocks of chlorophyll are expected to be higher; this may propagate through the food web and support higher standing stocks, growth rates and/or size of higher trophic-level predators like squid. Furthermore, the abundance and location of squid can also influence the distribution of higher trophic predators (Jaquet \& Gendron 2002). Studies of squid population dynamics thus need to consider the spatial and temporal biological and oceanographic influences when making assessments on squid growth and reproduction.

This study focused on the biology of the Australian arrow squid Nototodarus gouldi. There was little known about the growth dynamics of this species in Australia, although some surveys have previously documented aspects of the distribution and size composition in southern Australia (Machida 1983, Smith 1983, Dunning \& Förch 1998), along with diet (O'Sullivan \& Cullen 1983). Unlike many other ommastrephid species, N. gouldi is predominantly a continental shelf species, and is the dominant ommastrephid squid in continental shelf waters off SE Australia south of $27^{\circ} \mathrm{S}$ and around the North Island, and northern regions of the South Island, of New Zealand (Dunning 1998, Dunning \& Förch 1998). It is most abundant in a depth range of 50 to $200 \mathrm{~m}$ and can even enter shallow waters and estuaries, particularly during summer (Winstanley et al. 1983). The reproductive strategy of $N$. gouldi appears to be multiple spawning, with no evidence of somatic degradation due to gonad growth (McGrath \&
Jackson 2002). Extensive work has been previously carried out on the growth and biology of both N. gouldi and the New Zealand endemic N. sloanii in New Zealand waters (Uozumi 1998).

This study was aimed at filling the gaps in our knowledge of the spatial and temporal population dynamics of Nototodarus gouldi in southern Australian waters. Aspects of the variation in size, age, growth and maturity rates were explored using a statolithbased ageing technique.

\section{MATERIALS AND METHODS}

Samples were collected from 4 locations in southern Australia, over 2 seasonal periods, and repeated for 2 consecutive years. Squid samples were obtained from commercial fishing fleets from the fishing ports of: Ulladulla, New South Wales (Ull); Port Lincoln, South Australia (PL); Lakes Entrance, Victoria (LE); and Hobart, Tasmania (Tas) (Fig. 1A), hereafter referred to as Tasmania. The sampling regime was designed to obtain squid that had grown through the coolest or warmest periods: summer/autumn-caught (warm season squid, hereafter referred to as autumn squid) and spring-caught (cool season squid, hereafter referred to as spring squid). Samples were collected from all seasons except for Port Lincoln, where a spring 2001 sample was not obtained.

All samples were random, and obtained by commercial bottom trawl except for the summer/autumn Tasmania sample that was a combination of trawl and auto-jig-caught squid. Many of the samples for each location and date were pooled from several days of trawling (Table 1).

All squid were frozen upon capture and processed at the Institute of Antarctic and Southern Ocean Studies laboratory. Data recorded for each squid included sex, dorsal mantle length (ML, $\mathrm{mm})$, total weight and gonad weight $(\mathrm{g})$. Each squid was also assigned to a maturity stage that was modified from Lipinski (1979). Statoliths were removed, rinsed with water and stored dry at room temperature.

A sub-sample of statoliths was selected for age estimates from the complete size-range of individuals. Statoliths were mounted in the thermoplastic cement Crystal Bond on a microscope slide in preparation for ageing. Statoliths were ground dry on both the anterior and posterior plane to produce a thin section using $30 \mu \mathrm{m}$ lapping film, and polished using a $5.0 \mu \mathrm{m}$ lapping film.

Total increment counts were taken using a Nikon Eclipse E400 high-power microscope $(400 \times)$ using polarized light. The mean of 2 counts that varied less than $10 \%$ of the mean was taken as the age estimate in 
Table 1. Nototodarus gouldi. Collection details, including number of individuals aged and the sex ratio. ns $=$ non-significant, ${ }^{*} \mathrm{p}<0.05$, ${ }^{* *} \mathrm{p}<0.01,{ }^{* * *} \mathrm{p}<0.001$

\begin{tabular}{|c|c|c|c|c|c|c|c|c|}
\hline Location & Collection period & $\begin{array}{l}\text { Number of samples/ } \\
\text { day or hour of } \\
\text { sampling }\end{array}$ & $\begin{array}{l}\text { Method } \\
\text { of capture }\end{array}$ & $\begin{array}{c}\text { Total } \\
\text { number } \\
\text { caught }\end{array}$ & $\begin{array}{l}\text { Total } \\
\text { aged }\end{array}$ & $\begin{array}{l}\text { Males caught } \\
\text { (aged) }\end{array}$ & $\begin{array}{l}\text { Females caught } \\
\text { (aged) }\end{array}$ & $\begin{array}{c}\text { Sex ratio } \\
\text { F:M }\end{array}$ \\
\hline Ulladulla & $\begin{array}{l}\text { Late summer } 2000 \\
\text { Spring } 2000 \\
\text { Mid-autumn } 2001 \\
\text { Spring } 2001\end{array}$ & $\begin{array}{l}6 \text { trawls over } 2 \mathrm{~d} \\
2 \text { trawls over } 2 \mathrm{~d} \\
1-3 \mathrm{~h} \text { trawl } \\
3 \mathrm{~d} \text { trawling }\end{array}$ & $\begin{array}{l}\text { Trawl } \\
\text { Trawl } \\
\text { Trawl } \\
\text { Trawl }\end{array}$ & $\begin{array}{r}201 \\
197 \\
85 \\
53\end{array}$ & $\begin{array}{l}77 \\
74 \\
63 \\
53\end{array}$ & $\begin{array}{l}99(32) \\
79(35) \\
42(32) \\
22(22)\end{array}$ & $\begin{array}{c}102(45) \\
118(39) \\
43(31) \\
31(31)\end{array}$ & $\begin{array}{l}1: 1.03 \mathrm{~ns} \\
1: 1.49^{* *} \\
1: 1.02 \mathrm{~ns} \\
1: 1.41 \mathrm{~ns}\end{array}$ \\
\hline $\begin{array}{l}\text { Port } \\
\text { Lincoln }\end{array}$ & $\begin{array}{l}\text { Mid-autumn } 2000 \\
\text { Spring } 2000 \\
\text { Mid-autumn } 2001\end{array}$ & $\begin{array}{l}3 \mathrm{~d} \text { trawling } \\
2 \text { trawls over } 2 \mathrm{~d} \\
3 \mathrm{~d} \text { trawling }\end{array}$ & $\begin{array}{l}\text { Trawl } \\
\text { Trawl } \\
\text { Trawl }\end{array}$ & $\begin{array}{c}98 \\
172 \\
169\end{array}$ & $\begin{array}{l}64 \\
76 \\
67\end{array}$ & $\begin{array}{l}54(32) \\
85(37) \\
98(32)\end{array}$ & $\begin{array}{l}44(32) \\
87(39) \\
71(35)\end{array}$ & $\begin{array}{c}1: 0.81 \mathrm{~ns} \\
1: 1.02 \mathrm{~ns} \\
1: 0.72^{*}\end{array}$ \\
\hline $\begin{array}{l}\text { Lakes } \\
\text { Entrance }\end{array}$ & $\begin{array}{l}\text { Late summer } 2000 \\
\text { Spring } 2000 \\
\text { Mid-autumn } 2001 \\
\text { Spring } 2001\end{array}$ & $\begin{array}{l}\text { Squid from } 3 \text { boats } \\
\text { over } 4 \mathrm{~d} \\
1-5 \mathrm{~h} \text { trawl } \\
2 \text { trawls } \\
3 \text { trawls over } 2 \mathrm{~d}\end{array}$ & $\begin{array}{l}\text { Trawl } \\
\text { Trawl } \\
\text { Trawl } \\
\text { Trawl }\end{array}$ & $\begin{array}{c}128 \\
\\
237 \\
83 \\
128\end{array}$ & $\begin{array}{l}67 \\
66 \\
62 \\
68\end{array}$ & $\begin{array}{c}69(31) \\
152(31) \\
52(33) \\
86(33)\end{array}$ & $\begin{array}{l}59(36) \\
85(35) \\
31(29) \\
42(35)\end{array}$ & $\begin{array}{c}1: 0.85 \mathrm{~ns} \\
1: 0.56^{* * *} \\
1: 0.6^{*} \\
1: 0.49^{* * *}\end{array}$ \\
\hline Tasmania & $\begin{array}{l}\text { Late summer } 2000 \\
\text { Spring } 2000 \\
\text { Mid-autumn } 2001 \\
\text { Spring } 2001\end{array}$ & $\begin{array}{l}2 \mathrm{~d} \text { jigging } \\
3 \mathrm{~d} \text { trawling } \\
3 \mathrm{~d} \text { trawling } \\
4 \mathrm{~d} \text { trawling }\end{array}$ & $\begin{array}{l}\text { Auto jig } \\
\text { Trawl } \\
\text { Trawl } \\
\text { Trawl }\end{array}$ & $\begin{array}{c}96 \\
168 \\
150 \\
148\end{array}$ & $\begin{array}{l}53 \\
61 \\
65 \\
68\end{array}$ & $\begin{array}{l}24(19) \\
80(30) \\
76(32) \\
71(32)\end{array}$ & $\begin{array}{l}72(34) \\
88(31) \\
74(33) \\
77(36)\end{array}$ & $\begin{array}{c}1: 3^{* * *} \\
1: 1.1 \mathrm{~ns} \\
1: 0.97 \mathrm{~ns} \\
1: 1.08 \mathrm{~ns}\end{array}$ \\
\hline Total & & & & 2113 & 984 & $1089(463)$ & $1024(521)$ & \\
\hline
\end{tabular}

days. Most counts were very close to one another (within $5 \%$ ).

Initial validation work has provided some evidence of the daily periodicity of statolith increments in Nototodarus gouldi (G. D. Jackson unpubl. data). Furthermore, statolith ageing has also been suggested as daily in the congener N. sloanii in New Zealand, based on ageing of progressive modes (Uozumi 1998). Thus, the statolith increments were assumed daily for $N$. gouldi in this study.

Sea surface temperature/ocean colour. Weekly mean sea surface temperature (SST) off the coast from each of the sampling ports was calculated from the period of back-calculated hatching through the sampling period covered in this study. Data were sourced from the NOAA-CIRES Climate Diagnostic Centre

\section{A}

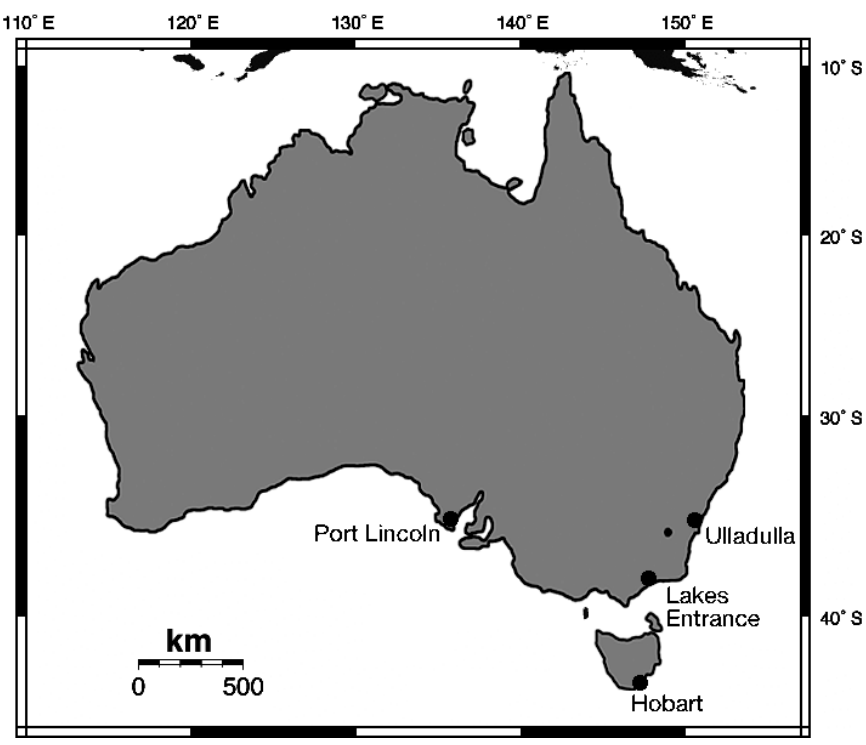

B

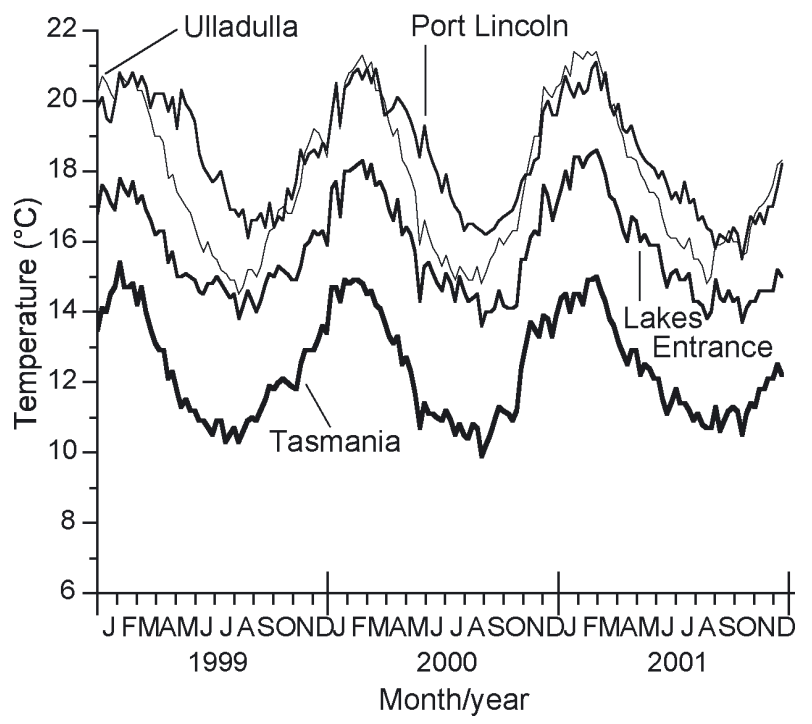

Fig. 1. (A) Map of Australia showing ports where squid were collected and (B) the seasonal trend in sea surface temperature for each location 
(available at www.cdc.noaa.gov/) (Reynolds et al. 2002).

We also explored the relationship between squid growth rates and local productivity as measured by SeaWiFS (Sea-viewing Wide Field-of-view Sensor), which provides quantitative data on optical properties of the ocean, and from these the standing stock of chl a (a measure of phytoplankton) is calculated (e.g. Joint \& Groom 2000). It is often assumed that measured standing stock (colour) is proportional to productivity (Joint \& Groom 2000), and thus sea surface colour (SSC) is often used as a proxy for chlorophyll productivity. SeaWiFS measures the colour from the upper 20 to $30 \mathrm{~m}$ of the surface ocean; in very clear waters, it may include deeper portions, while in more turbid waters it will represent a thinner surface layer (Joint \& Groom 2000, Wilson et al. 2002). In addition, the relationship between SSC and the whole water column chlorophyll value is poorly known for most regions of the world (Joint \& Groom 2000). A subsurface chlorophyll maximum is evident in many regions, and if deeper than the depth visible to the satellite, may not be detectable. This results in bias when estimating the water column standing stock of chlorophyll. A further caveat is that it is generally accepted that in coastal waters, the chl a concentration may need to be tuned to local conditions, as the inherent optical properties of constituents such as dissolved organic matter and suspended sediments vary strongly and can bias the apparent chlorophyll concentration. In this study, we assumed that the SSC data are representative of the upper surface layer at each site, and that they are a reasonable measure of local productivity.

A measure of squid growth rate (the slope of the log-log age-size relationships, see Table 3) for the sex/site/season combinations was related to a proxy for productivity (SSC). The SSC data were derived from the SeaWiFS 8 d $9 \mathrm{~km}$ chl a product, and average values for each $8 \mathrm{~d}$ period for a $1^{\circ}$ box at each location for the period 1999 to 2001 were obtained using customized Matlab programs. The $1^{\circ}$ boxes were centred so that the edge of the box touched the coast; Port Lincoln $\left(136^{\circ} \mathrm{E}, 35^{\circ} \mathrm{S}\right)$, Lakes Entrance $\left(148^{\circ} \mathrm{E}, 38.5^{\circ} \mathrm{S}\right)$, Ulladulla $\left(151^{\circ} \mathrm{E}, 35^{\circ} \mathrm{S}\right)$, and Tasmania $\left(147.6^{\circ} \mathrm{E}\right.$, $43.7^{\circ} \mathrm{S}$ ). These SSC data were then averaged to provide a monthly time series for each of the 4 locations, and the average SSC value for the months of peak hatching (as determined from back-calculated statolith ages) for each location was calculated. For the purpose of this study, we had to assume that hatchling and juvenile squid occur in the same region as the adults. Because there was a difference between locations in SSC and in the growth rate between males and females, the growth anomaly (difference from the mean) for each site and sex, rather than absolute values, was used in the analyses to allow sites to be combined. Similarly, the anomaly from the average SSC values for the months of peak spawning from each location was used.

Statistical analyses. Sexual dimorphism was determined for mature individuals by performing Bonferonni-adjusted $t$-tests to compare both log body-weight and $\log$ ML between the sexes, for each combination of location, season and year. This was carried out for all samples except Tasmania spring 2000 and autumn 2001, where there were insufficient males to test for sexual dimorphism.

Furthermore, we wanted to know whether arrow squid were schooling with the same sex or if there were mixed schools. This was analysed using a chisquare test that determined whether the number of males and females in each sample was significantly different than 1:1.

Growth, along with weight, age and gonad weight of mature individuals, was compared across locations, sexes, seasons and years using factorial ANOVA. In each case, location, sex, season and year were all treated as fixed factors. Where the presence of highorder interactions was indicated, pair-wise comparisons amongst groups were computed using the logical constraints method of Westfall (1997), except where otherwise stated.

Growth was analysed by fitting a separate-lines regression model to the log-transformed weight-at-age data to determine the effects of location, season, year and sex on body weight, with age as the covariate. Since growth data are more closely influenced by conditions experienced post-hatching, and especially during the juvenile stage, individuals were grouped according to the season of hatch. Season of hatch was grouped in 3 to 4 mo periods (e.g. late summer-mid-autumn and winter-spring). However, since maturity is more related to conditions at time of capture, analyses using mature individuals were grouped according to time of capture.

Differences in the mean log weight (which equates to the median weight on the original untransformed data) of mature males and females were analysed separately due to sexual dimorphism in this species. A 3-way full factorial ANOVA, with location, season of capture and year as the factors of interest, was used to determine differences in body weight for males and females. For females, Tasmanian spring-caught 2000 and autumn-caught 2001 samples were removed due to there being less than 5 mature individuals in the samples. Mature animals in this and all subsequent analyses included both Stage 4 and 5 individuals. The Stage 4 squid were considered functionally mature, even though at that time there was no evidence of eggs in the oviducts of females or spermatophores in Needham's sac of males. 
We were interested in exploring the effects of location, season of capture, and year on median gonad weight for mature males and females separately. For males, a 3-way full factorial ANOVA was used to test differences in median testis weight, and for females a 3-way full factorial ANOVA was used to test differences in median ovary weight. These data were extremely unbalanced due to samples with less than 5 individuals being removed from the analysis, as it was not clear that these samples would be truly representative.

The age of mature males and females was analysed together as sex was a factor of interest. To determine the effects of location, season of capture, year and sex on the mean age of mature individuals, a 4-way full factorial ANOVA, with the 4-way interaction removed, was used. Female samples from Tasmania springcaught 2000 and autumn-caught 2001, as well as Ulladulla autumn-caught 2001 were removed due to less than 5 mature individuals in these samples. This resulted in $0 \mathrm{df}$ for the 4 -way interaction. When a significant interaction or main effect was obtained from the ANOVA model on mean age, body size or gonad weight, a Tukey's HSD was used to determine where significant differences were occurring.

\section{RESULTS}

The squid were obtained from temperate Australian waters, between approximately 35 and $43^{\circ} \mathrm{S}$ (Fig. 1A), that were subject to marked seasonal fluctuations in SST. There was a general decrease in water temperature from Port Lincoln/Ulladulla to Lakes Entrance and Tasmania (Fig. 1B). There was no overlap in SST between Tasmania and Lakes Entrance and the other sites. However, of the 2 warmer sites, Ulladulla was more variable, with considerably cooler winter temperatures but warmer summer temperatures compared to Port Lincoln. There were no marked differences in the seasonal trend of SST among the years of study.

\section{Sexual dimorphism and sex ratios}

At all locations and times, except Ulladulla in the autumn of 2001, significant differences were found between the median ML and median weight of males and females, with females being considerably heavier than males (Fig. 2). The median weight for mature females ranged between 1.27 and 2.46 times heavier than the median weight of mature males, while the median ML for females ranged between 1.1 and 1.37 times longer than males. Ulladulla squid were consistently the smallest individuals, with the majority of mature individuals weighing $<500 \mathrm{~g}$. This contrasted with Tasmania, where most mature individuals were $>500 \mathrm{~g}$. Lakes Entrance squid tended to be larger, with the majority also $>500 \mathrm{~g}$, while Port Lincoln squid were intermediate in size, and variable over time, with some samples having median weights $>500 \mathrm{~g}$ and other samples having weights $<500 \mathrm{~g}$ (Fig. 2).

Out of a total of 15 samples, the majority $(\mathrm{n}=9)$ showed no difference in the female-to-male (F:M) sex ratio (Table 1). For those samples that did show significant differences in sex ratios, 4 had a majority of females and only 2 had a majority of males.

\section{Growth}

A total of 2113 squid were sampled in this study, and of these, 984 were aged using statolith increment counts and their data used in age and growth analyses (Table 1). Growth of Nototodarus gouldi was rapid, and 
the life cycle appeared to be less than $1 \mathrm{yr}$, as the oldest squid we aged was $329 \mathrm{~d}$. The oldest immature female was $275 \mathrm{~d}$ from Tasmania, while the youngest mature female was $171 \mathrm{~d}$ from Ulladulla. The oldest immature male was 229 d from Tasmania, while the youngest mature male was $142 \mathrm{~d}$ from Ulladulla. Ulladulla individuals were the smallest and youngest, while Port Lincoln and Lakes Entrance had the oldest individuals (Fig. 3). Since both axes were logged to linearise the data, growth was described by a power curve in all instances (Table 2).

The separate-lines regression showed a significant 4 -way interaction of location $\times$ season $\times$ year $\times \operatorname{sex}(F=4.31, \mathrm{df}=2,922, \mathrm{p}=$ $0.014)$. Because of the complexity of interaction and the presence of the missing cell (a sample was not obtained for Port Lincoln in spring 2001), the subsequent analysis relied on a series of pair-wise comparisons of slopes within gender and location subgroups to discern patterns of growth. Our pair-wise analysis of slopes of all locations/times resulted in far too many comparisons to readily interpret. We therefore split the data into sub-groups by location, season and year and made comparisons within these subgroups. Not all comparisons were significantly different, but for those that were, there was a general trend across all locations of individuals growing significantly faster in 1999-2000 (Year 1) compared to individuals that hatched in late 2000-early 2001 (Year 2). Furthermore, there was also a consistent trend of summer/autumn-hatched individuals growing faster than winter/spring-hatched individuals (Table 3).

Comparisons between locations revealed that Ulladulla females and males grew significantly faster than Port Lincoln and Lakes Entrance females in Year 1 winter/spring. In Year 2 winter/spring, Ulladulla females and males and Lakes Entrance females grew significantly faster than Lakes Entrance males. There were no significant differences in the growth of summer/autumn-hatched squid for both sexes at all locations in Year 1. However in Year 2, Ulladulla females grew significantly faster than Ulladulla and Tasmania males. Lakes Entrance females also grew significantly faster than Tasmania males.

There was a significant positive relationship between the growth rate anomaly and the SSC anomaly for female squid from the winter/spring period (regression, $F_{1,6}=6.20, \mathrm{p}<0.05, \mathrm{R}^{2}=0.51$ ) but not for the summer/autumn period (Fig. 4). There was no significant relationship between the growth of male squid and productivity in either season. When productivitygrowth relationships at individual sites were considered all were non-significant, perhaps due in part to small sample size ( $\mathrm{n}=4$ samples per site, 3 for Port

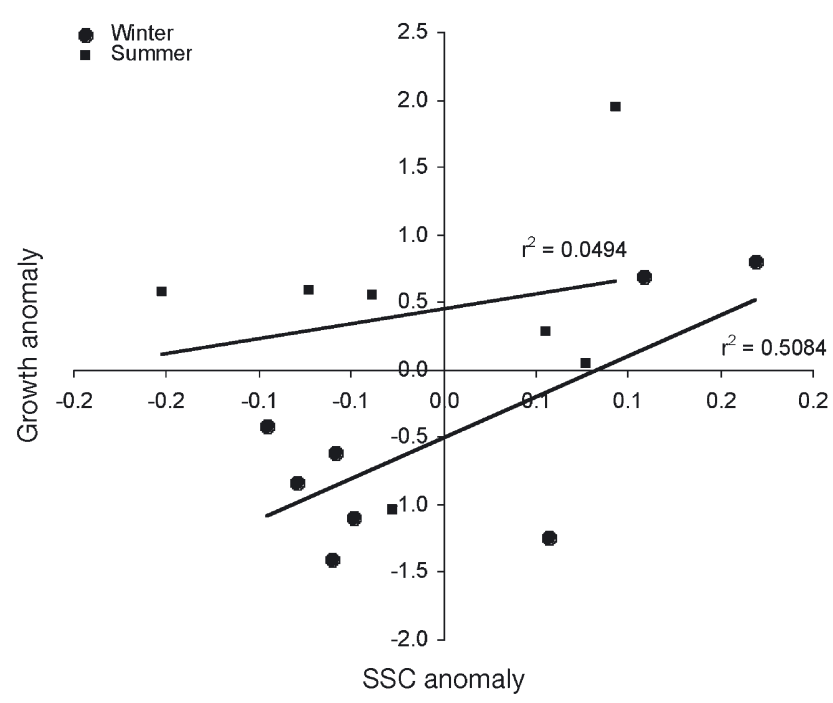

Fig. 4. Nototodarus gouldi. Relationship between productivity (sea surface colour; SSC) and growth anomalies for females from summer and winter periods ( $\mathrm{n}=7$ and 8 , respectively) 
Table 2. Nototodarus gouldi. Regression details for the relationship between age and weight for male (M) and female (F) individuals from all locations, seasons and years sampled in this study grouped according to hatch period. ${ }^{*} \mathrm{p}<0.05,{ }^{* *} \mathrm{p}<0.01,{ }^{* * *} \mathrm{p}<0.001$

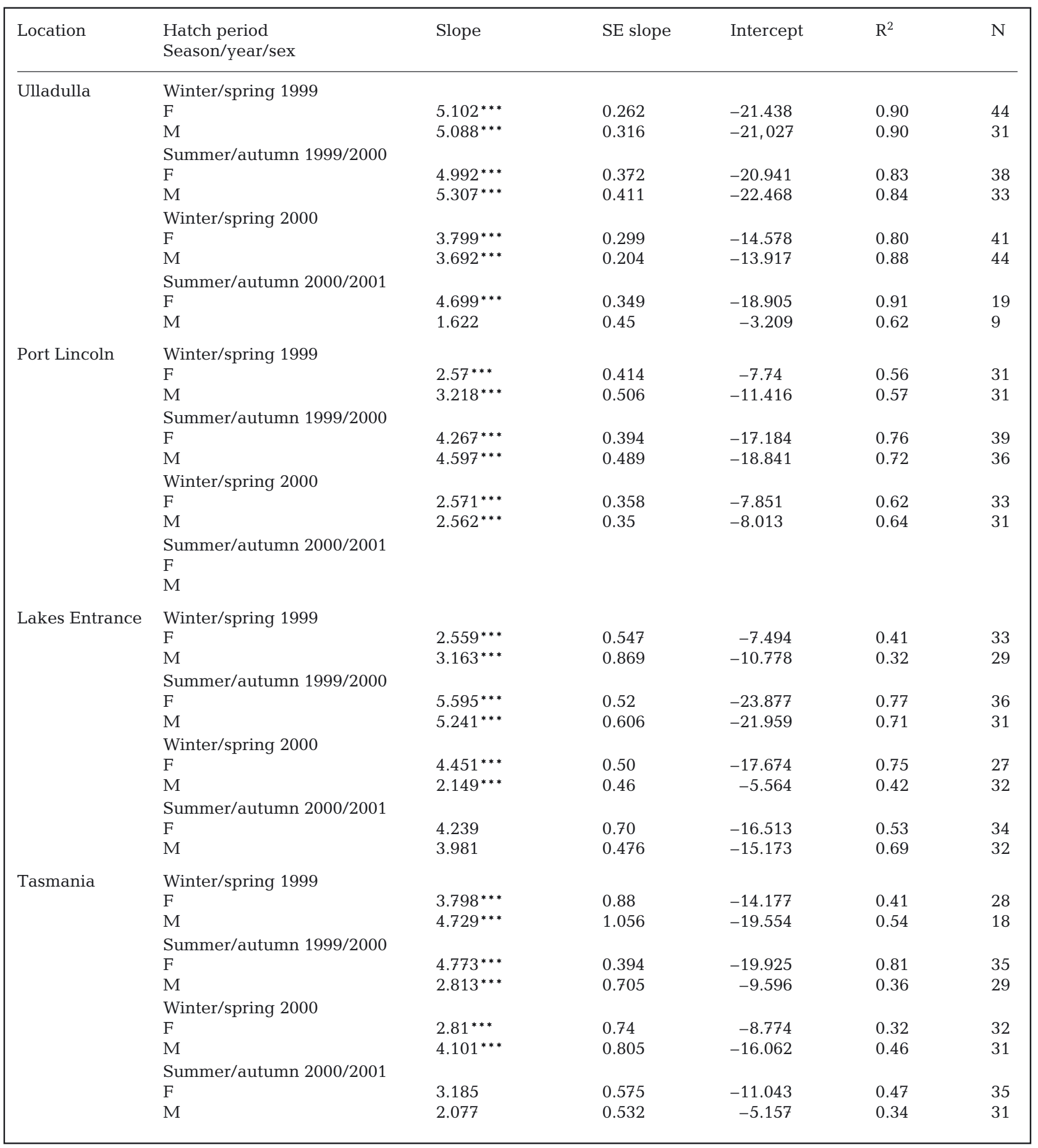

Lincoln). As before, however, there was a positive relationship between SSC and growth rate for females (relationship strength for Port Lincoln > Lakes Entrance $>$ Ulladulla $>$ Tasmania), while for males the relationship went from weakly positive to negative in the same location order).
Based on a sub-sample of aged individuals, it was possible to determine hatch-periods (Fig. 5). The hatching periods for the Port Lincoln squid differed from the other 3 sites, and had hatch peaks in spring during 1999 and in autumn and winter during 2000. Tasmania and Lakes Entrance had similar hatching periods that oc- 
Table 3. Nototodarus gouldi. Summary of growth rates grouped according to location. The combination of sex, year and hatch season in left column are squid with significantly greater growth rates than squid in the right column. p-values refer to pair-wise comparisons; sum: summer; aut: autumn; win: winter; spr: spring

\begin{tabular}{|c|c|c|c|c|}
\hline Location & $\begin{array}{l}\text { Sex/year/ } \\
\text { hatch season }\end{array}$ & & $\begin{array}{l}\text { Sex/year/ } \\
\text { hatch season }\end{array}$ & p-value \\
\hline \multirow[t]{4}{*}{ Ulladulla } & Females Yr 1 sum/aut & $>$ & Males Yr 2 win/spr & 0.028 \\
\hline & Males Yr 1 sum/aut & $>$ & $\begin{array}{l}\text { Females Yr } 2 \text { win/spr } \\
\text { Males Yr } 2 \text { win/spr }\end{array}$ & $\begin{array}{l}0.022 \\
0.009\end{array}$ \\
\hline & Males Yr 1 win/spr & $>$ & $\begin{array}{l}\text { Males Yr } 2 \text { win/spr } \\
\text { Females Yr } 2 \text { win/spr }\end{array}$ & $\begin{array}{l}0.008 \\
0.022\end{array}$ \\
\hline & Females Yr 1 win/spr & $>$ & $\begin{array}{l}\text { Males Yr } 2 \text { win/spr } \\
\text { Females Yr } 2 \text { win/spr }\end{array}$ & $\begin{array}{l}0.005 \\
0.019\end{array}$ \\
\hline \multirow[t]{2}{*}{$\begin{array}{l}\text { Port } \\
\text { Lincoln }\end{array}$} & Males Yr 1 sum/aut & $>$ & $\begin{array}{l}\text { Females Yr } 1 \text { win/spr } \\
\text { Females Yr } 2 \text { win/spr } \\
\text { Males Yr } 2 \text { win/spr }\end{array}$ & $\begin{array}{l}0.018 \\
0.005 \\
0.010\end{array}$ \\
\hline & Females Yr 1 sum/aut & $>$ & $\begin{array}{l}\text { Females Yr } 1 \mathrm{win} / \mathrm{spr} \\
\text { Femals Yr } 2 \mathrm{win} / \mathrm{spr} \\
\text { Males Yr } 2 \mathrm{win} / \mathrm{spr}\end{array}$ & $\begin{array}{l}0.030 \\
0.009 \\
0.018\end{array}$ \\
\hline \multirow[t]{2}{*}{$\begin{array}{l}\text { Lakes } \\
\text { Entrance }\end{array}$} & Males Yr 1 sum/aut & $>$ & $\begin{array}{l}\text { Females Yr } 1 \text { win/spr } \\
\text { Males Yr } 2 \text { win-spr }\end{array}$ & $\begin{array}{l}0.015 \\
0.001\end{array}$ \\
\hline & Females Yr 1 sum/aut & $>$ & $\begin{array}{l}\text { Females Yr } 1 \mathrm{win} / \mathrm{spr} \\
\text { Males Yr } 2 \mathrm{win} / \mathrm{spr}\end{array}$ & $\begin{array}{l}0.003 \\
0.000\end{array}$ \\
\hline Tasmania & Females Yr 1 sum/aut & $>$ & Males Yr 2 sum/aut & 0.003 \\
\hline
\end{tabular}

spring 2001 males that were significantly smaller than all other samples. The Port Lincoln autumn 2001 males were intermediate in weight and were significantly different from all other samples. The plasticity in weight of mature males is highlighted by the difference between the heaviest and lightest males (Tasmania autumn vs Ulladulla spring 2000), where the difference in the medians was a striking $290 \%$ (586.3 vs $150.3 \mathrm{~g}$ ). All regions except for Lakes Entrance showed a marked decrease in weight for springcaught males as opposed to autumncaught males.

Females. The weight of mature females only showed evidence of a location $\times$ season interaction $\left(F_{\mathrm{W}}=13.03\right.$, $\mathrm{df}=2,301, \mathrm{p}=0.0001)$. However, this was interpreted cautiously as there were missing cells and evidence of higher-order interactions for the males. curred during winter and autumn 1999/2000, and during spring and autumn 2000/2001. Ulladulla had hatch periods during spring 1999, autumn and spring 2000 and autumn 2001. These hatch peaks would be related to the fact that we had 4 distinct sample periods during the study (except for Port Lincoln, which had 3), which back-calculated to 4 distinct hatch periods in the study. Therefore, it is likely that hatching occurs throughout the year, and the peaks identified in our study are due to distinct sampling periods, rather than suggesting distinct spawning periods.

\section{Reproductive analyses}

Mean size and age of mature individuals

Males. Due to sexual dimorphism, the median weight of mature males and females was analysed separately. Males had a significant location $\times$ season $\times$ year interaction $\left(F_{\mathrm{W}}=21.79\right.$, df $=2,822$, p $\left.<0.001\right)$. There were 2 predominant weight groupings for the male squid (Fig. 6). The heaviest males were from Tasmania, Lakes Entrance and Port Lincoln for both seasons in 2001, and Lakes Entrance and Tasmania for autumn 2000, and none of these samples were significantly different. The smaller males were from the spring samples from Port Lincoln and Tasmania in 2000, and both seasons for Ulladulla in both years. All the small males were similar, except for Ulladulla

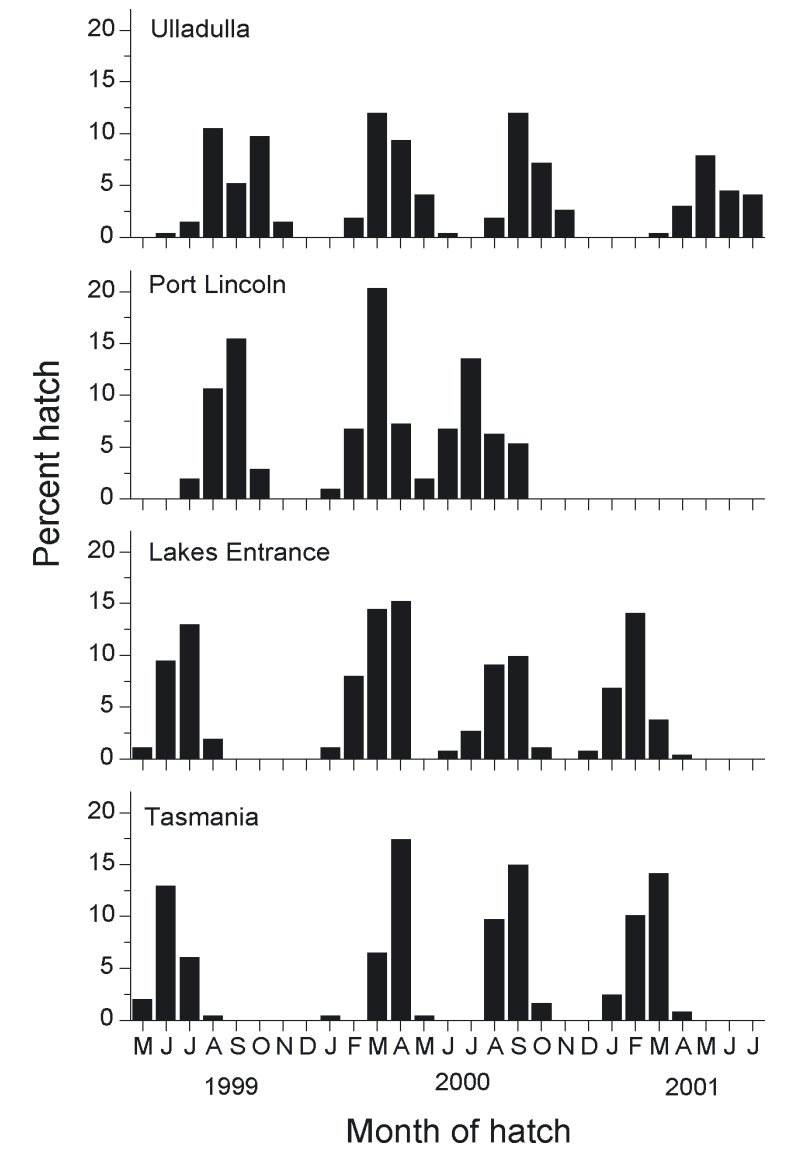

Fig. 5. Nototodarus gouldi. Hatch date distribution for all the aged individuals from each of the collection ports 

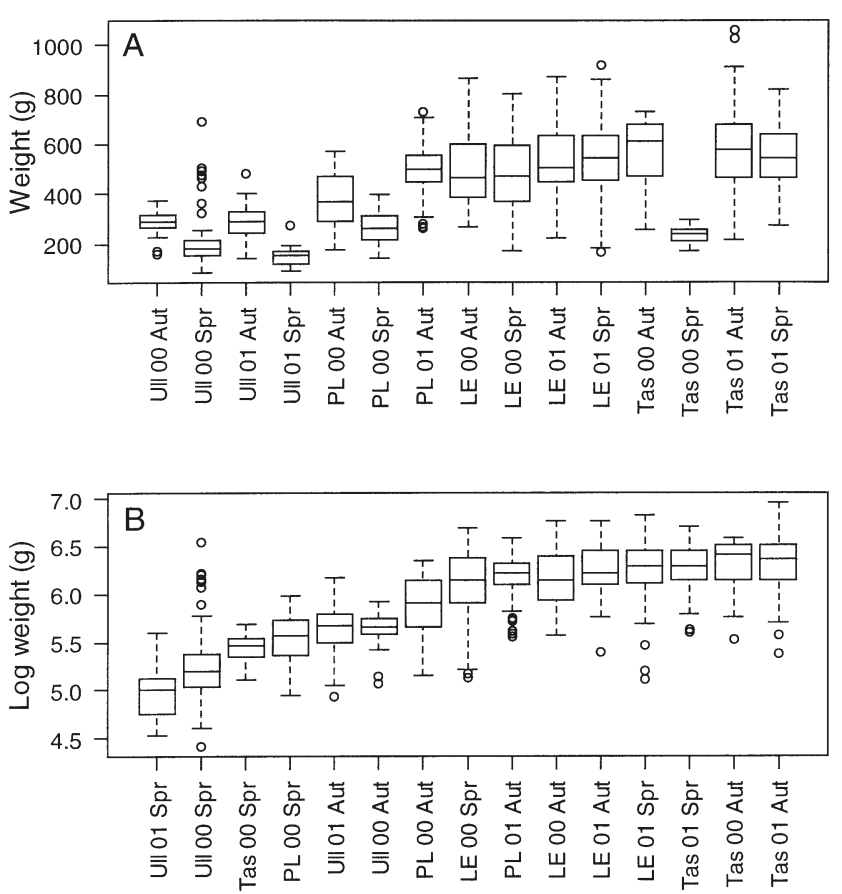

Fig. 6. Nototodarus gouldi. Distribution of mature male weights according to (A) location and (B) the distribution of logged mature male weights, shown sequentially. See Fig. 2 legend for abbreviations; circles indicate individuals that are outliers

We therefore fit a model uniquely to the Lakes Entrance and Ulladulla locations for which there were no missing cells, but also attained the same result of only a location $\times$ season interaction $\left(F_{\mathrm{W}}=8.05, \mathrm{df}=\right.$ $1,155, \mathrm{p}=0.01$ ). We therefore could not detect a yearly difference in weight of mature females. The Ulladulla samples were the smallest in weight, and were significantly different from all other sites, while the largest females that were, for the most part, indistinguishable in weight, were from Tasmania autumn 2000, spring 2001; Lakes Entrance spring 2000, autumn 2000/2001 and Port Lincoln 2001 autumn. Port Lincoln autumn 2000 and Lakes Entrance autumn 2000 were intermediate between the grouping of small and large females (Fig. 7). The only significant difference in seasonal weight of mature females was found in Port Lincoln 2000, where the autumn females were significantly heavier than their spring counterparts.

\section{Age}

There was considerable variation in age of mature individuals for location, year and season (Fig. 8A). The Ulladulla spring 2001 male sample had the youngest mean age of $165 \mathrm{~d}$, while the Port Lincoln autumn 2001 females had the oldest mean age of $280 \mathrm{~d}$. A grouping
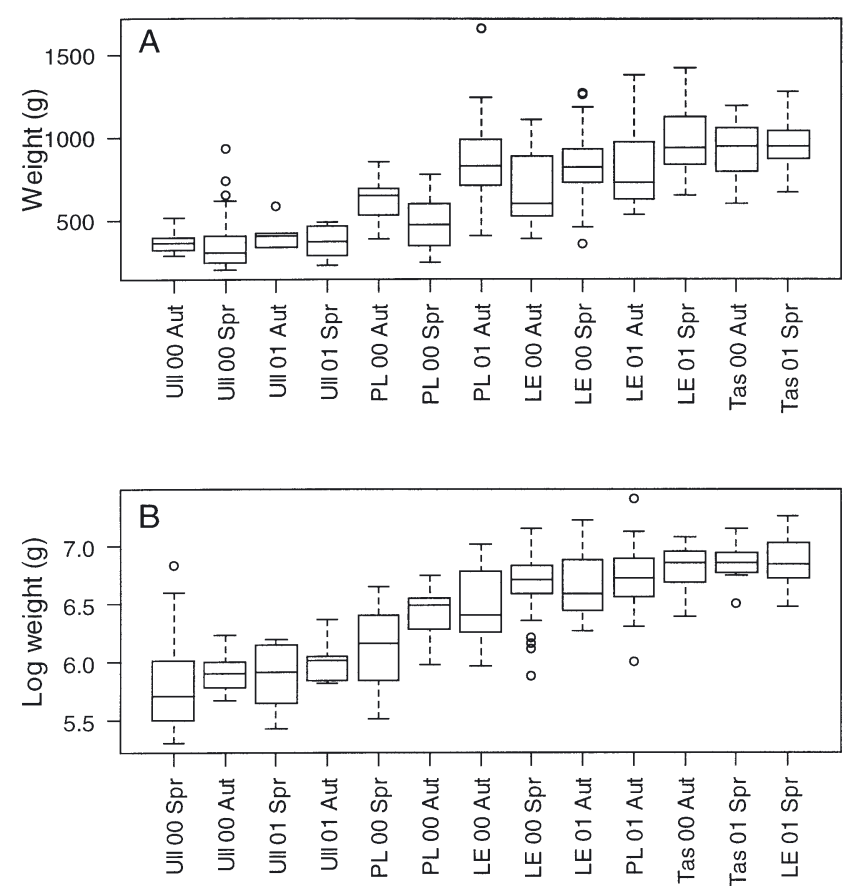

Fig. 7. Nototodarus gouldi. Distribution of mature female weights according to (A) location and (B) the distribution of logged male weights, shown sequentially. See Fig. 2 legend for abbreviations; circles indicate individuals that are outliers
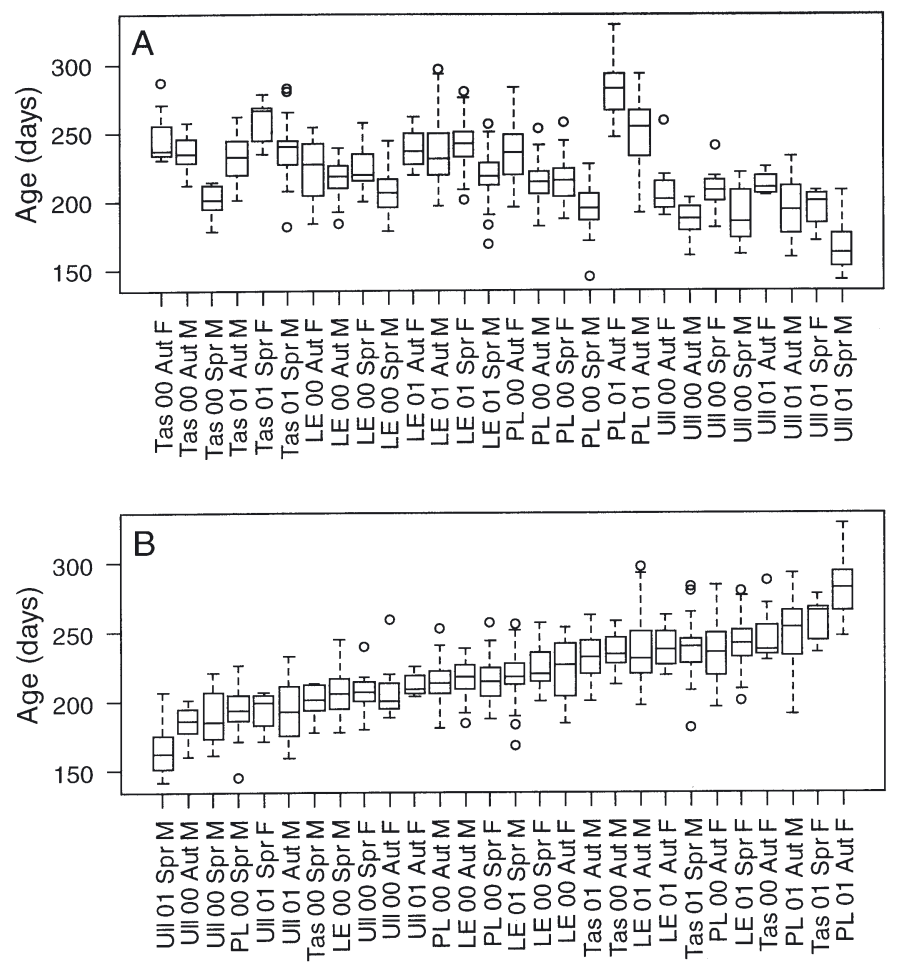

Fig. 8. Nototodarus gouldi. Distribution of mature male (M) and female (F) ages according to (A) location and (B) increasing age. See Fig. 2 legend for abbreviations; circles indicate individuals that are outliers 
of Ulladulla samples generally had the youngest individuals, while Tasmania and Port Lincoln formed another group that had the oldest individuals, with the Lakes Entrance squid being somewhat intermediate in age (Fig. 8A). Port Lincoln was the most variable of the samples, and although Port Lincoln had the oldest squid, the spring 2000 male sample had a young mean age of $194 \mathrm{~d}$ and grouped with the younger Ulladulla samples. Similarly, the Tasmania spring 2000 males were also considerably younger than the other Tasmanian samples. Thus, although there were overall trends, those 2 young Tasmanian and Port Lincoln samples fell considerably outside the trend in age for each location.

A full factorial model resulted in a significant location $\times$ season $\times$ year interaction $\left(F_{\text {age }}=18.98, \mathrm{df}=2,532\right.$, $\mathrm{p}=0.0001$ ). Since sex was not a significant factor, we re-ran the ANOVA with all 3-way interactions with sex removed, but this did not modify our initial findings. We therefore undertook Bonferonni-adjusted pairwise comparisons of mean age. The pairwise comparisons revealed that there was a continuum in mean age rather than any clear groupings. When grouped according to increasing mean age, there was just a gradual trend of increasing age from Ulladulla spring 2001 males to Port Lincoln autumn 2001 females (Fig. 8B).

\section{Average gonad weights of mature individuals}

Males

The trend in gonad weights of mature individuals differed between males and females. The 3-way full factorial ANOVA of testis weight resulted in a 3-way interaction (location $\times$ season $\times$ year $)\left(F_{\text {testis weight }}=\right.$ 24.47, df $=2,818, \mathrm{p}<0.0001$ ). There were no consistent trends across locations (Fig. 9). However, there were 2 predominant groupings in testis weights: (1) those with lighter testis weights, which were indistinguishable from each other (Tasmania spring 2000, Ulladulla spring 2000, spring and autumn 2001, and Port Lincoln spring and autumn 2000); and (2) those with heavier testis weights, also indistinguishable from each other (Port Lincoln autumn 2001, all the Lakes Entrance samples, and Tasmania autumn 2000, spring 2001). Ulladulla spring 2001 males had the smallest testis weights, and this sample was significantly different from all other samples except for Tasmania spring 2000. Interestingly, Tasmania autumn 2001 had an intermediate testis weight that was significantly different from all other weights, except for Tasmania autumn 2000. The difference between the largest median testis weight (7.36 g, Lakes Entrance spring 2001) and the smallest median testis weight (2.25 g,
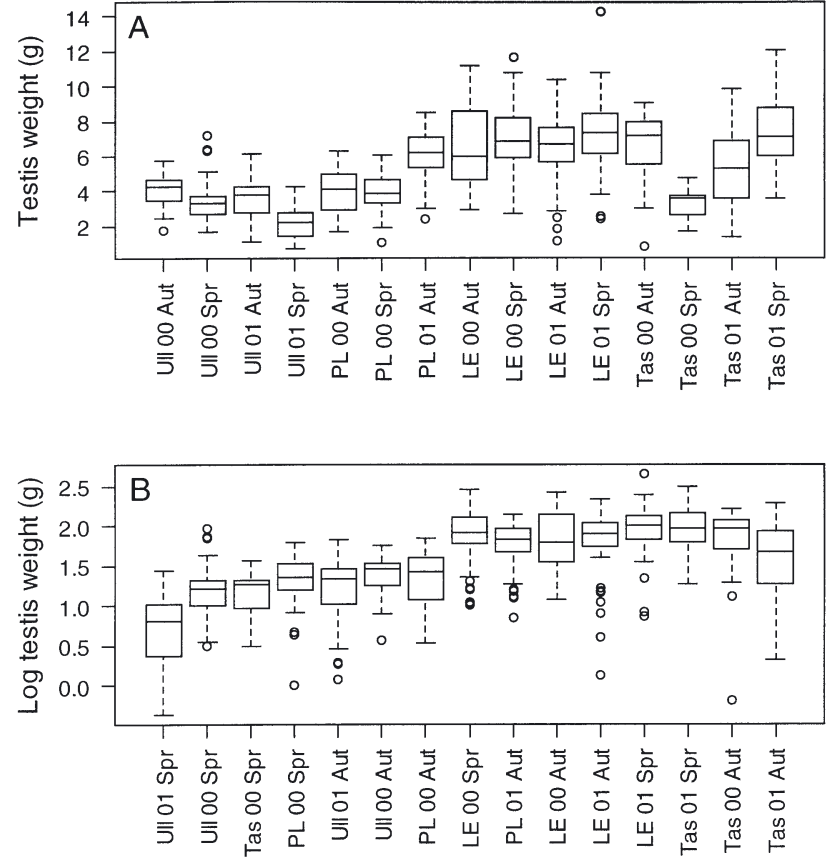

Fig. 9. Nototodarus gouldi. Distribution of mature male testis weights according to (A) location and (B) the distribution of logged mature male testis weights, shown sequentially. See Fig. 2 legend for abbreviations; circles indicate individuals that are outliers

Ulladulla spring 2001) was $227 \%$. The only consistent seasonal trend was that both Tasmania 2000 and Ulladulla 2001 had males with significantly lighter testis weights in spring compared to autumn.

Females

Fitting a factorial model to the females alone showed evidence of a location $\times$ season interaction $\left(F_{\text {ovary weight }}=\right.$ 3.25 , df $=3,290, \mathrm{p}<0.05)$, which was consistent with the results for body weight. There were no subsets without missing cells to fit a comparative model to. Groupings of the pair-wise comparisons were less distinct, and predominantly revealed a trend in increasing ovary weight across samples, with Ulladulla consistently showing the smallest ovary weights (Fig. 10). The only significant seasonal trends in ovary weight were in Port Lincoln 2000, where ovary weight in spring was significantly less than autumn, and Lakes Entrance 2000, where the trend was reversed, with autumn squid having ovaries that weighed significantly less than spring squid. The difference between the largest median ovary weight (48.65 g, Lakes Entrance spring 2001) and the smallest median ovary weight (17.53 g, Ulladulla autumn 2000) was $177.5 \%$. 

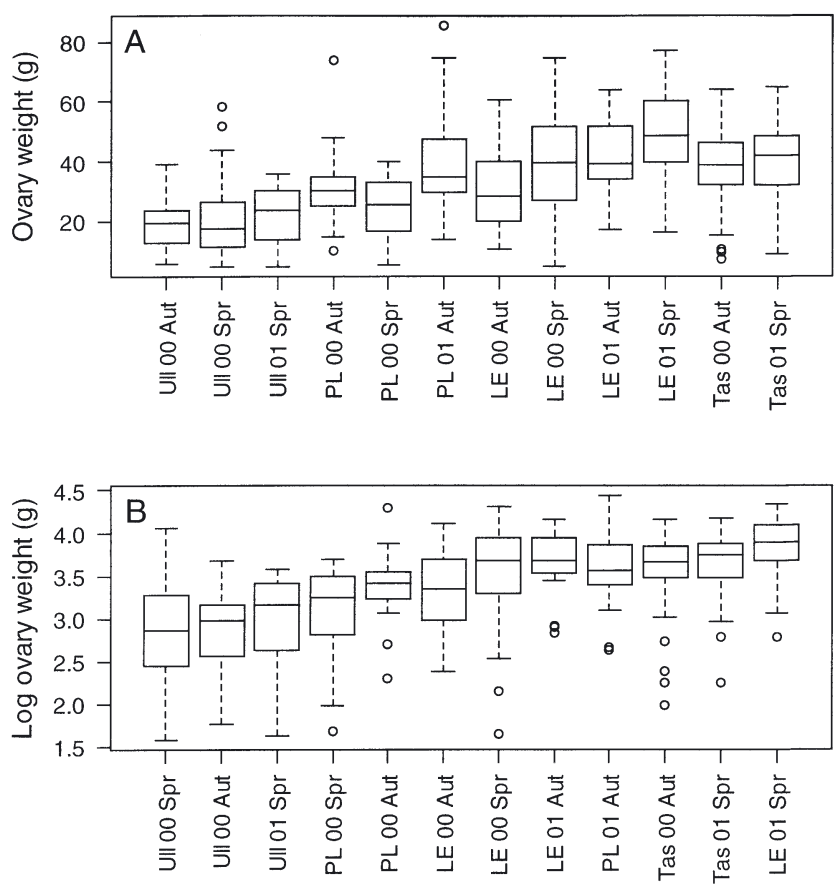

Fig. 10. Nototodarus gouldi. Distribution of mature female ovary weights according to (A) location and (B) the distribution of logged mature female ovary weights, shown sequentially. See Fig. 2 legend for abbreviations; circles indicate individuals that are outliers

\section{Trends in maturity stages}

Males

There were marked differences in the distribution of maturity stages between sexes and locations (Fig. 11). Mature Stage 4 and 5 males were generally the most common for Tasmania (except spring 2000, where most were immature), Port Lincoln and Lakes Entrance. While mature males were also predominant in Ulladulla samples, there was generally a greater mix of maturity stages in the Ulladulla samples.

\section{Females}

The trend in maturity stages was much more variable for females, with a much greater range in maturity stages across sampling sites (Fig. 10). Mature females were generally less abundant in all Ulladulla samples, and in spring 2000 and autumn 2001 samples in Tasmania. Mature females were more abundant in the autumn samples for Port Lincoln and in both seasons during 2001 for Lakes Entrance.

\section{DISCUSSION}

This study revealed just how variable the dynamics of squid populations can be over time and space. We had initially planned a more robust analysis by pooling the seasonal samples over the $2 \mathrm{yr}$ of study. However, the unexpected difference in the growth dynamics of squid over the 2 yr prevented this from happening and added another layer of complexity to the analysis. What we found was a spectrum of patterns influenced by sites, sexes, seasons and years. While some trends were visible, i.e. we can state that Ulladulla squid are smaller than Lakes Entrance squid, it is difficult to state the magnitude of these differences. There is also a clear lack of consistency. For example, mature Tasmanian male squid are generally large, with median weights greater than $400 \mathrm{~g}$; however, in spring 2000 the mature males were considerably smaller $(<300 \mathrm{~g})$ and grouped with the Ulladulla males (Fig. 5). The mature males and females from Port Lincoln also show considerable variability in weight depending on the time of capture.

\section{Trends in size}

The differences in the weight of squid were interesting. Females appear to achieve their larger size by 
predominantly growing faster than males, rather than living longer. Why the marked difference in size for the same species over spatial and temporal scales? Perhaps most dramatic is the small body size of the Ulladulla individuals. These squid of both sexes were consistently the smallest and youngest, and generally had the smallest gonads. However, as noted above, they seem to sit at the smaller end of the continuum, as there were some samples from other locations that overlapped with the Ulladulla squid (e.g. low median weights for Port Lincoln and Tasmanian spring 2000 males).

The general trends (small squid in low latitudes and bigger squid in higher latitudes) shown in this study can be best explained in terms of latitudinal differences in temperature. Squid in the cooler water live longer and grow bigger. Such trends have been found in other species sampled over large geographical distances. Pecl (2001) found that individuals of the large Australian loliginid squid Sepioteuthis australis were smaller and younger from the low latitude site of Newcastle, New South Wales, compared to the higher latitude site of Tasmania. Over even greater distances, Jackson \& Moltschaniwskyj (2001) found individuals of the warm water population of the loliginid S. lessoniana in tropical Thailand waters to be considerably smaller and younger than those of the sub-tropical population in south Queensland, Australia. These 2 growth strategies were referred to as 'hot' and 'cool' strategies. Interestingly, in between these 2 sample sites, off Townsville, north Queensland, Jackson \& Moltschaniwskyj (2002) found that this mid-population alternated between these 2 growth patterns depending on season, with winter-hatched squid displaying the 'cool' growth strategy and summer-hatched squid displaying the 'hot' strategy. Similar differences have also been found between tropical and temperate female populations of the loliginid Loliolus noctiluca in Eastern Australia (Jackson \& Moltschaniwskyj 2001). Similarly, populations of Loligo pealeii off northeastern North America show geographic differences in body size with cooler northern waters having larger individuals than warmer southern waters, at least during some seasonal periods (Hatfield \& Cadrin 2002). Similar trends in cooler zone, bigger, slower-growing squid vs warmer zone, smaller, faster-growing squid have also been observed in Todarodes sagittatus populations from the north Atlantic (Rosenberg et al. 1981) compared to tropical Africa (Arkhipkin et al. 1999). Arkhipkin (1996) also found geographical differences in size and growth rates in different populations of Illex coindetii in tropical waters off western Africa. However, it was not possible to relate this to environmental conditions, as hatching and juvenile environments were not known.

\section{Age and growth}

Trying to establish trends and influences of growth of Nototodarus gouldi populations in southern Australia was likewise challenging. Some general trends were readily interpretable from known responses of squid to temperature (e.g. Forsythe et al. 2001, Jackson \& O'Dor 2001). This is demonstrated by the fact that all squid cohorts hatching out in warmer summer/autumn conditions (at each location) had higher growth rates than cooler winter/spring-hatched squid (Table 3). However, we were surprised by the consistency of each seasonal cohort at each location, in that squid hatched in Year 1 (1999/2000) often had significantly faster growth rates than the squid from the corresponding site/season during Year 2 (2000/2001). Furthermore, it was never the other way around; there were never any gender groups in Year 2 that had faster growth rates than the corresponding group in Year 1.

Interestingly, productivity levels, as indicated by SSC back-calculated to time of hatching, did provide some answers (at least for females). Higher productivity at a given location, as indicated by the SSC anomaly, resulted in faster winter growth for females, but not summer growth. This may be because temperature is the dominant environmental factor in summer, while at cooler winter temperatures, productivity becomes relatively more important. Indeed, the growth anomaly was greater in waters with the highest average SSC (Port Lincoln and Lakes Entrance). The use of such remotely sensed productivity information has immense potential for determining factors of species abundance and recruitment success (Platt et al. 2003).

The productivity analysis was taken from the time of peak squid-hatching at each location. It is, however, possible that conditions before or after spawning could be more important in determining female growth rates. Alternative critical periods for squid, with regard to local productivity and other oceanographic conditions (such as SST), are being investigated in a separate study. These more complex analyses may also help to explain differences in male growth with respect to productivity.

Productivity for squid collected at each site was estimated within a $1^{\circ}$ box adjacent to that site. The spawning location of the squid is unknown, as is the location of squid prior to capture. It is possible that the local productivity estimates were not always related to the environment that the squid experienced during their post-hatching/juvenile phase. Seasonal changes in circulation could result in squid populations originating in different regions, or relying on productivity from different regions. Without additional information on the movements of squid, more appropriate areas of study cannot be selected. It is believed that this species does not move great distances over its life, in contrast to 
other ommastrephids (e.g. Illex argentinus, Waluda et al. 2001; I. Illecebrosus, Todarodes pacificus, O'Dor 1992). In fact, earlier tagging studies have found that Nototodarus gouldi is not highly migratory, with populations having relatively restricted distributions (Dunning \& Förch 1998). Food can have a more important overriding influence than temperature, as recently suggested for populations of Loligo opalescens off California (Jackson \& Domeier 2003) and Todarodes angolensis (Villanueva 1992) off Africa, where higher growth rates in squid were attributed to periods of higher productivity, rather than higher temperatures.

It is notable that the yearly discrepancies in growth rates were consistent over such a large geographical region, and this suggests that the squid are possibly responding to broad-scale oceanographic influences. It does appear that the squid responses can be used as ecosystem indicators, as suggested by Jackson \& Domeier (2003). The variable growth patterns are probably influenced predominantly by local and seasonal patchiness in the environment, as suggested for Illex illecebrosus off Nova Scotia (Arkhipkin \& Perez 1998).

As is typical with other squid populations, the life span of Nototodarus gouldi in Australian waters does not appear to exceed a year. Such short life spans mean that squid can rapidly respond to differing environmental conditions. The growth strategy is also surprisingly similar to the southern Australian teleost blue sprat Spratelloides robustus, which has rapid growth and a short life span $(<300$ d) in South Australian waters (Rogers et al. 2003). The age data are similar to those that were found for $N$. gouldi and N. sloanii in New Zealand waters by Uozumi (1998), although older specimens of $N$. gouldi $>1 \mathrm{yr}$ were found in the New Zealand study. $N$. gouldi appears to live longer than its smaller tropical congener $N$. hawaiiensis, which appears to complete its life cycle in <200 d (Jackson \& Wadely 1998).

Our data suggest that Nototodarus gouldi have protracted spawning, with hatching taking place during all seasons of the year. This would contribute to a complex population structure. Year-round hatching has also been documented for $N$. gouldi in New Zealand waters (Uozumi 1998).

\section{Do small morphs exist at Ulladulla?}

The consistent small size and shorter life spans of the Ulladulla population suggest that environmental conditions are pushing Nototodarus gouldi to its biological and physiological limits in this region. O'Dor \& Lipinski (1998) have suggested that such differences can be caused by either a latitudinal cline in size-at-maturity or genetic isolation leading to distinct growth and mat- uration patterns regardless of temperature. Jackson \& Yeatman (1996) also described a cline in size and age at maturity in tropical Photololigo populations, and suggested that it might be a combination of environmental, genetic and behavioural factors influencing the cline.

Initial allozyme electrophoresis of the Nototodarus gouldi population across southern Australia has not found evidence for different species being present (Triantafillos et al. unpubl.). Rather, there seems to be considerable genetic mixing across southern Australia. We cannot, however, discount genetically distinct regional populations. The fact that Ulladulla-like squid appear in other places (e.g. Tasmania or Port Lincoln) at certain times suggests that squid populations might be responding rapidly to short-term environmental events. Perhaps Ulladulla is self-recruiting and is selecting for 'hot genes' (O'Dor 1998), while Tasmania is maintaining a population of 'cold genes' (or genes selecting for other special characteristics). However, under certain instances, environmental constraints might cause a drastic change in the gene frequencies of the population, thus supporting a population during that season with different gene frequencies than 'normal' for the region. Different morphs have been described for other ommastrephid squid species. Both Dosidicus gigas and Sthenoteuthis oualaniensis have 2 size morphs. Anderson \& Rodhouse (2001) have suggested an environmental mechanism controlling these morphs, with squid encountering more productive waters growing faster, reaching bigger overall sizes and delaying maturity. We suspect that it is probably a combination of changes in gene frequencies, along with environmental influences, that shape the structure of $N$. gouldi populations to maintain such marked plasticity in age and growth in southern Australia. Ulladulla squid might be special morphs, but flexibility in the population dynamics allow 'Ulladulla-like morphs' to appear at other locations, should the appropriate conditions prevail. The complexity in size and age can be viewed in light of the Anderson \& Rodhouse (2001) hypothesis.

\section{Maturity}

Comparing mature individuals across samples provided a means to scale across all locations/times. The weight of mature individuals further emphasised the discrepancy in size among locations. There were 3 general trends: (1) large mature individuals at Tasmania and Lakes Entrance; (2) extremely small individuals at Ulladulla; and (3) pronounced variability at Port Lincoln. The lack of predictability in size is especially apparent in the weight of mature Tasmanian male squid. Notably, the autumn and spring 2001 samples showed very little variation in median size (ca. $500 \mathrm{~g}$ ). 
However, these contrasted markedly with the 2000 spring sample, where individuals were predominantly $<300 \mathrm{~g}$, noticeably younger and grouped with the Ulladulla males. This outlying group goes against general ecological trends of size and age with latitude as discussed above. Our highest latitude squid from Tasmania can alter their life history characteristics to such an extent that they mirror the life history of much lower latitude congeners.

The variation in both weight and age of mature Port Lincoln squid of both sexes is also intriguing. The weight and age of mature individuals at Port Lincoln was variable and inconsistent over time. This suggests that perhaps squid off Port Lincoln may be subject to a more variable environment compared to the other sites.

\section{Conclusion}

Nototodarus gouldi shows extreme plasticity in growth, body size and reproductive tactics. While there are some general trends apparent, it is the variability in many of the parameters that stand out. $N$. gouldi appears to adapt rapidly to varying environmental conditions, and is a successful and abundant species of the southern Australian continental-shelf ecosystem. The life style of $N$. gouldi and its success in this ecosystem reflects the adaptability of this species. The extreme phenotypic variability is a prime example of the ultimate law of biology - 'whatever works, works' (O'Dor 1998). The fact that this species appears to be so adaptable suggests that it will probably act as an ideal ecosystem indicator and productivity integrator, as has been shown for Loligo opalescens (Jackson \& Domeier 2003). Despite the comprehensive site, season and location sampling strategy in this study, a longer time-series is probably necessary to interpret the patterns in growth and reproduction in N. gouldi. Further analyses incorporating both SST and SSC during different periods of the life cycle may also help to explain growth variation as a response to biological and oceanographic conditions experienced by individuals. More regular samples within a location would also reveal life-style changes in this species at a greater resolution.

Acknowledgements. This work was funded by a Fisheries Research and Development Corporation research grant awarded to G.D.J. (ID 1999/112). We would like to thank the fishers at the key ports who assisted with collecting squid for this study. We are grateful to S. Tracey, who provided SST data. SeaWiFS data was supplied by Thomas Moore and CMR Remote Sensing, courtesy of the NASA SeaWiFS Project and the Goddard Earth Sciences Data and Information Services Center/Distributed Active Archive Center.

\section{LITERATURE CITED}

Agnew DJ, Beddington JR, Hill SL (2002) The potential use of environmental information to manage squid stocks. Can J Fish Aquat Sci 59:1851-1857

Anderson CIH, Rodhouse PG (2001) Life cycles, oceanography and variability: ommastrephid squid in variable oceanographic environments. Fish Res 54:133-143

Arguelles J, Rodhouse PG, Villegas P, Castillo G (2001) Age, growth and population structure of the jumbo flying squid Dosidicus gigas in Peruvian waters. Fish Res 54:51-61

Arkhipkin A (1996) Geographical variation in growth and maturation of the squid Illex coindetii (Oegopsida, Ommastrephidae) off the north-west African coast. J Mar Biol Assoc UK 76:1091-1106

Arkhipkin A, Perez JAA (1998) Life history reconstruction. In: Rodhouse PG, Dawe EG, O'Dor RK (eds) Squid recruitment dynamics. Food and Agriculture Organization, Rome, p 157-180

Arkhipkin A, Laptikhovsky V, Golub A (1999) Population structure and growth of the squid Todarodes sagittatus (Cephalopoda: Ommastrephidae) in north-west African waters. J Mar Biol Assoc UK 79:467-477

Arkhipkin A, Jereb P, Ragonese S (2000) Growth and maturation in two successive seasonal groups of the short-finned squid, Illex coindetii from the Strait of Sicily (central Mediterranean). ICES J Mar Sci 57:31-41

Dawe EG, Beck PC (1997) Population structure, growth, and sexual maturation of short-finned squid (Illex illecebrosus) at Newfoundland. Can J Fish Aquat Sci 54:137-146

Dunning MC (1998) Zoogeography of arrow squids (Cephalopoda: Ommastrephidae) in the Coral and Tasman Seas, Southwest Pacific. Smith Cont Zool 586:435-454

Dunning MC, Förch EC (1998) A review of the systematics, distribution, and biology of Arrow Squids of the Genus Nototodarus Pfeffer, 1912 (Cephalopoda: Ommastrephidae). Smithsonian Contrib Zool 586:393-404

Forsythe JW, Walsh LS, Turk PE, Lee PG (2001) Impact of temperature on juvenile growth and age at first egglaying of the Pacific reef squid Sepioteuthis lessoniana reared in captivity. Mar Biol 138:103-112

Garrison LP, Michaels W, Link JS, Fogarty MJ (2002) Spatial distribution and overlap between ichthyoplankton and pelagic fish and squids on the southern flank of Georges Bank. Fish Oceanogr 11:267-285

Hatfield EMC (2000) Do some like it hot? Temperature as a possible determinant of variability in the growth of the Patagonian squid, (Cephalopoda: Loliginidae). Fish Res $47: 27-40$

Hatfield EMC, Cadrin SX (2002) Geographic and temporal patterns in size and maturity of the longfin inshore squid (Loligo pealeii) off the northeastern United States. Fish Bull 100:200-213

Hatfield EMC, Hanlon RT, Forsythe JW, Grist EPM (2001) Laboratory testing of a growth hypothesis for juvenile squid Loligo pealeii (Cephalopoda: Loliginidae). Can J Fish Aquat Sci 58:845-857

Jackson GD, Domeier ML (2003) The effects of an extraordinary El Niño/La Niña event on the size and growth of the squid Loligo opalescens off southern California. Mar Biol 142:925-935

Jackson GD, Moltschaniwskyj NA (2001) Temporal variation in growth rates and reproductive parameters in the small near-shore tropical squid, Loliolus noctiluca; is cooler better? Mar Ecol Prog Ser 218:167-177

Jackson GD, Moltschaniwskyj NA (2002) Spatial and temporal variation in growth rates and maturity in the Indo- 
Pacific squid Sepioteuthis lessoniana (Cephalopoda: loliginidae). Mar Biol 140:747-754

Jackson GD, O'Dor RK (2001) Time, space and the ecophysiology of squid growth, life in the fast lane. Vie Milieu 51: 205-215

Jackson GD, Wadley VA (1998) Age, growth and reproduction of the tropical squid Nototodarus hawaiiensis (Cephalopoda: Ommastrephidae) off the North West Slope of Australia. Fish Bull 96:779-787

Jackson GD, Yeatman J (1996) Variation in size and age-atmaturity in Photololigo from the North West Shelf of Australia. Fish Bull 94:59-65

Jackson GD, Forsythe JW, Hixon RF, Hanlon RT (1997) Age, growth and maturation of Lolliguncula brevis (Cephalopoda: loliginidae) in the northwestern Gulf of Mexico with a comparison of length-frequency vs. statolith age analysis. Can J Fish Aquat Sci 54:2907-2919

Jaquet N, Gendron D (2002) Distribution and relative abundance of sperm whales in relation to key environmental features, squid landings and the distribution of other cetacean species in the Gulf of California, Mexico. Mar Biol 141:591-601

Joint I, Groom SB (2000) Estimation of phytoplankton production from space: current status and future potential of satellite remote sensing. J Exp Mar Biol Ecol 250:233-255

Kang YS, Kim JY, Kim HG, Park JH (2002) Long-term changes in zooplankton and its relationship with squid, Todarodes pacificus, catch in Japan/East Sea. Fish Oceanogr 11:337-346

Lipinski MR (1979) Universal maturity scale for the commercially-important squids (Cephalopoda: Teuthoidea). The results of maturity classification of the Illex illecebrosus (LeSueur, 1821) populations for the years 1973-1977. Doc 79/II/38, Int Comm Northwest Atl Fish Res, Dartmouth, Nova Scotia

Machida S (1983) A brief review of the squid survey by Hoyo Maru No 67 in southeast Australian waters in 1979/80. Mem Natl Mus Vict 44:291-295

Macy WK III, Brodziak JKT (2001) Seasonal maturity and size at age of Loligo pealeii in waters of southern New England. ICES J Mar Sci 58:852-864

McGrath BL, Jackson GD (2002) Egg production in the arrow squid Nototodarus gouldi (Cephalopoda: Ommastrephidae), fast and furious or slow and steady? Mar Biol 141: 699-706

O'Dor RK (1992) Big squid in big currents. S Afr J Mar Sci 12: 225-235

O'Dor RK (1998) Squid life-history strategies In: Rodhouse PG, Dawe EG, O'Dor RK (eds) Squid recruitment dynam-

Editorial responsibility: Otto Kinne (Editor),

Oldendorf/Luhe, Germany ics. Food and Agriculture Organization, Rome, p 233-254

O'Dor RK, Lipinski MR (1998) The genus Illex (Cephalopoda; Ommastrephidae): characteristics, distribution and fisheries. In: Rodhouse PG, Dawe EG, O'Dor RK (eds) Squid recruitment dynamics. Food and Agriculture Organization, Rome, p 1-12

O'Sullivan D, Cullen JM (1983) Food of the squid Nototodarus gouldi in Bass Strait. Aust J Mar Freshw Res 34:261-285

Pecl G (2001) Flexible reproductive strategies in tropical and temperate Sepioteuthis squids. Mar Biol 138:93-101

Platt T, Fuentes-Yaco C, Frank KT (2003) Spring algal bloom and larval fish survival. Nature 423:398-399

Reynolds RW, Rayner NA, Smith TM, Stokes DC, Wang W (2002) An improved in situ and satellite SST analysis for climate. J Climate 15:1609-1625

Rodhouse PG (2001) Managing and forecasting squid fisheries in variable environments. Fish Res 54:3-8

Rogers PJ, Geddes M, Ward TM (2003) Blue sprat Spratelloides robustus (Clupeidae: Dussumieriinae): a temperate clupeoid with a tropical life history strategy? Mar Biol 142: 809-824

Rosenberg AA, Wiborg KF, Bech IM (1981) Growth of Todarodes sagittatus (Lamarck) (Cephalopoda, Ommastrephidae) from the north-east Atlantic, based on counts of statolith growth rings. Sarsia 66:53-57

Smith HK (1983) Fishery and biology of Nototodarus gouldi (McCoy, 1888) in Western Bass Strait. Mem Natl Mus Vict 44:285-290

Uozumi Y (1998) Fishery biology of arrow squids, Nototodarus gouldi and N. sloanii, in New Zealand waters. Bull Natl Res Inst Far Seas Fish 35:1-111

Villanueva R (1992) Interannual growth differences in the oceanic squid Todarodes angolensis Adam in the northern Benguela upwelling system, based on statolith growth increment analysis. J Exp Mar Biol Ecol 159:157-177

Waluda CM, Rodhouse PG, Podesta GP, Trathan PN, Pierce GJ (2001) Surface oceanography of the inferred hatching grounds of Illex argentinus (Cephalopoda: Ommastrephidae) and influences on recruitment variability. Mar Biol 139:671-679

Westfall P (1997) Multiple testing of general contrasts using logical constraints and correlations. J Am Stat Assoc 92: 299-306

Wilson RP, Grémillet D, Syder J, Kierspel MAM and 6 others (2002) Remote-sensing systems and seabirds: their use, abuse and potential for measuring marine environmental variables. Mar Ecol Prog Ser 228:241-261

Winstanley RH, Potter MA, Caton AE (1983) Australian cephalopod resources. Mem Natl Mus Vict 44:243-253

Submitted: June 20, 2003; Accepted: September 27, 2003

Proofs received from author(s): November 26, 2003 